The Philosophical Journal of Conflict and Violence

Vol. V, Issue $1 / 2021$

(C) The Authors 2021

Available online at http://trivent-publishing.eu/

\title{
Beyond Military Humanitarian Intervention: From Assassination to Election Hacking?
}

\author{
Alexander Leveringhaus \\ Department of Politics \& Centre for International Intervention (cii), \\ University of Surrey, United Kingdom
}

\begin{abstract}
This paper critically examines the implications of technology for the ethics of intervention and vice versa, especially regarding (but not limited to) the concept of military bumanitarian intervention (MHI). To do so, it uses two recent pro-interventionist proposals as lenses through which to analyse the relationship between interventionism and technology. These are A. Altman and C.H. Wellman's argument for the assassination of tyrannical leaders, and C. Fabre's case for foreign electoral subversion. Existing and emerging technologies, the paper contends, play an important role in realising these proposals. This illustrates the potential of technology to facilitate interventionist practices that transcend the traditional concept of MHI, with its reliance on kinetic force and largescale military operations. The question, of course, is whether this is normatively desirable. Here, the paper takes a critical view. While there is no knockdown argument against either assassination or electoral subversion for humanitarian purposes, both approaches face similar challenges, most notably regarding public accountability, effectiveness, and appropriate regulatory frameworks. The paper concludes by making alternative suggestions for how technology can be utilised to improve the protection of human rights. Overall, the paper shows that an engagement with technology is fruitful and necessary for the ethics of intervention.
\end{abstract}

\section{Keywords}

Just War Theory; Humanitarian Intervention; Human Rights; Drones; Information Technology.

\section{DOI: 10.22618/TP.PJCV.20215.1.139007}

The PJCV Journal is published by Trivent Publishing

\section{$\nabla_{\text {TRIVENT }}$
TRE}

This is an Open Access article distributed in accordance with the Creative Commons Attribution Non Commercial (CC$B Y-N C$-ND 4.0) license, which permits others to copy or share the article, provided original work is properly cited and that this is not done for commercial purposes. Users may not remix, transform, or build upon the material and may not distribute the modified material (bttp:/ / creativecommons.org/ licenses/by-nc/4.0/) 


\title{
Beyond Military Humanitarian Intervention: From Assassination to Election Hacking?
}

\author{
Alexander Leveringhaus \\ Department of Politics \& Centre for International Intervention (cii), \\ University of Surrey, United Kingdom
}

\begin{abstract}
This paper critically examines the implications of technology for the ethics of intervention and vice versa, especially regarding (but not limited to) the concept of military humanitarian intervention (MHI). To do so, it uses two recent pro-interventionist proposals as lenses through which to analyse the relationship between interventionism and technology. These are A. Altman and C.H. Wellman's argument for the assassination of tyrannical leaders, and C. Fabre's case for foreign electoral subversion. Existing and emerging technologies, the paper contends, play an important role in realising these proposals. This illustrates the potential of technology to facilitate interventionist practices that transcend the traditional concept of $M H I$, with its reliance on kinetic force and largescale military operations. The question, of course, is whether this is normatively desirable. Here, the paper takes a critical view. While there is no knockdown argument against either assassination or electoral subversion for humanitarian purposes, both approaches face similar challenges, most notably regarding public accountability, effectiveness, and appropriate regulatory frameworks. The paper concludes by making alternative suggestions for how technology can be utilised to improve the protection of human rights. Overall, the paper shows that an engagement with technology is fruitful and necessary for the ethics of intervention.
\end{abstract}

\section{Keywords}

Just War Theory; Humanitarian Intervention; Human Rights; Drones; Information Technology.

\section{Introduction}

In this paper, I critically analyse the implications of military and civilian technologies for the ethics of intervention, and especially the concept of military humanitarian intervention (MHI). This is an issue that is commonly neglected in the philosophical literature on intervention, and hence the paper plugs an important gap in the marketplace. To appreciate why technology is so crucial to interventionism, consider Michael Ignatieff's famous account of NATO's air campaign against Serbia during the Kosovo War in $1999 .{ }^{1}$ During the war, NATO, Ignatieff opines, did most of the fighting, while the Serbs did most of the dying. Indeed, there seemed to be a mismatch of the risks of combat. One side, NATO, faced few risks to its personnel, while the other side had to bear the full brunt of war. Even more than two decades after the

\footnotetext{
${ }^{1}$ Michael Ignatieff, Virtual War: Kosovo and Beyond (London: Vintage, 2001).
} 
Kosovo War, it remains contested whether NATO's tactic of high-altitude bombing, with planes flying at over $10000 \mathrm{ft}$, as well as its targeting of Serbian dual-use infrastructure (used for civilian and military purposes), was ethically defensible.

It is not hard to see, though, why NATO chose the above tactics. The Kosovo War was not fought against an aggressor that had threatened a NATO member state. Rather, it was waged in defence of Kosovo Albanians who were, during the breakup of Yugoslavia at the end of the Cold War, threatened by ethnic cleansing at the hands of Serbian forces. Could NATO's member states really have been expected to put their service personnel in harm's way to defend individuals not located in their territories? Without the availability of technologies that allowed targeting from a position of relative safety, one wonders whether NATO, already acting reluctantly at the time, would have been willing to intervene in the conflict between ethnic Albanians and Serbs. As the examples of Kosovo and also NATO's later intervention in Libya in 2011 indicate, advances in weapons technology seemingly render boots on the ground unnecessary. ${ }^{2}$ Yet, since NATO's justification for military action in 1999 appealed to the human rights of Kosovo Albanians, it would have been morally and politically self-defeating if NATO's methods had been excessively harmful. Hence, during the Kosovo War, the concepts of precision and precision-targeting played an important justificatory role for NATO. The alliance was keen to stress, rightly or wrongly, that its technological superiority ensured that its actions did not undermine its humanitarian objectives.

These brief reflections indicate that the ethical debate on MHI, as well as the philosophical treatment of interventionism more broadly, is often (implicitly) shaped by assumptions about the availability of certain technologies. Against this background, the paper critically asks the following two questions. First, could existing and emerging technologies facilitate forms of interventionism that transcend the classic concept of MHI? Second, are these alternative forms of interventionism morally desirable? To answer these questions, the paper discusses two recent proposals by pro-interventionist philosophers. The first proposal, by Andrew Altman and Christopher Heath Wellman, argues in favour of using assassinations to protect human rights. Below, I consider whether, in the context of this proposal, drones (uninhabited aerial vehicles) could, and should, be used to carry out assassinations. The second proposal, by Cécile Fabre, contends that in order to protect human rights, it is sometimes permissible to subvert elections in another state. Just as drones could render a policy of humanitarian assassination more feasible, information technology and other digital technologies could render foreign electoral subversion more feasible than it would have been at the time of the Kosovo War or even the more recent Libya intervention.

Before we can analyse these two proposals, let me raise three quick points of clarification. First, the two proposals under examination neither describe unprecedented state behaviour nor novel political practices nor even novel technologies. That said, the mere existence of a political phenomenon or technology tells us nothing about its moral desirability, which is very much the issue in this paper. Further, by focussing on the ethics of intervention, the paper provides an angle less commonly found in debates over drone strikes and electoral subversion. Second, my aim in this paper is not exegetical. I merely use the two proposals as springboards and lenses for an examination of the relationship between technology and interventionism. Needless to say, the following analysis represents my own interpretation of the material, for which the aforementioned authors should not be held responsible. Third, perhaps uncharacteristically for the analytical style of theorising, I will draw upon relevant historical and contemporary examples throughout the paper. This is not to say that I endorse

\footnotetext{
${ }^{2}$ In the case of Kosovo, it is not quite correct to say that there were no boots on the ground. NATO supported the KLA (Kosovo Liberation Army) in its operations against Serbian forces. See Tim Judah, Kosovo: War and Revenge, $2^{\text {nd }}$ ed (New Haven: Yale University Press, 2002).
} 
a form of moral casuistry at a methodological level. Rather, just as the Kosovo War reveals the key role of airpower and precision-weaponry in MHI, the practical examples in this paper throw the respective ethical and practical issues arising from assassinations and foreign electoral subversion into sharp relief. With these three clarifications in place, I begin the analysis by briefly exploring the classic conception of MHI. This is because, for the purpose of this paper, the two proposals under consideration need to be seen in relation to the more established concept of MHI.

\section{The Classic Concept of Military Humanitarian Intervention and Technology}

To begin, it is necessary to offer a definition of MHI. The following two features are often cited to classify non-self-defensive uses of force as MHIs:

1. An intervening party, usually a state or group of states, uses military force in order to intervene in the internal affairs and sovereign domain of another state [the target state], without obtaining that states' consent.

2. The non-consensual use of force, either unilaterally or multilaterally, is morally justified because

a. the target state treats its members systematically and on a large-scale in an illicit manner, and

b. in doing so violates fundamental and universal moral values.

By morally justified I mean that the intervening party is under no moral duty not to intervene in the target state's internal affairs, and there are strong moral reasons in favour of its actions. As a result, the intervening party does not violate any moral rights held by the target state against foreign powers not to interfere with its internal affairs.

In a philosophical context, the concept of $\mathrm{MHI}$ is usually embedded within contemporary just war theory and its two classic normative frameworks, jus ad bellum and jus in bello. The former framework regulates the initiation of the use of military force. In its classic formulation, jus ad bellum features the following criteria: 1) just cause, 2) proportionality, 3) necessity, 4) reasonable likelihood of success, 5) last resort, and 6) right authority. By contrast, just war theory's second normative framework, jus in bello, is concerned with the conduct of hostilities once an armed conflict is underway. It contains two key criteria: distinction [belligerents must distinguish between legitimate and illegitimate targets] and proportionality [harm must not be excessive to the good achieved]. While much ink has been spilled over the two jus frameworks, it is not necessary to wade into these complex debates here.

Instead, let us briefly outline the two main positions on MHI taken by political philosophers. Michael Walzer's seminal Just and Unjust Wars: A Moral Argument with Historical Illustrations serves as the starting point for the contemporary ethical debate on MHI. ${ }^{3}$ In this work, Walzer's main argument is that states qua members of international society hold rights against other states not to aggress them or otherwise interfere in their internal affairs (without their consent). This is because states play an instrumental role in protecting and preserving the integrity of the political communities that reside within their territories. That said, Walzer concedes, there are exceptions to the prohibition on intervention when "crimes that shock the conscience of mankind" occur in a state's territory, including genocide, enslavement and the forcible resettlement of populations. Lacking an explicit reference to human rights

\footnotetext{
${ }^{3}$ Michael Walzer, Just and Unjust Wars: A Moral Argument with Historical Illustrations, $5^{\text {th }}$ ed (New York:
} Basic Books, 2015), chapter 6. 
discourse and the liberal and democratic connotations associated with it, Walzer's notion of crimes that shock the conscience of mankind seeks to restrict MHI to few exceptional circumstances. Hence, I refer to his position as minimalist interventionism.

Since the publication of Just and Unjust Wars in 1977, less restrictive positions on MHI have emerged, which I refer to as maximalist interventionism. Notwithstanding theoretical differences between individual theories, maximalist positions are generally rooted in a version of contemporary philosophical liberalism, with a strong emphasis on universalism, moral individualism, and human rights. For example, Cécile Fabre contends that the purpose of MHI is to protect civil, political and socio-economic human rights, subject to further conditions. ${ }^{4}$ At least in theory, this allows for more frequent interventions than Walzer would countenance.

Fernando Tesón, one of Walzer's earliest critics, uses an intriguing thought experiment to make a somewhat similar point to Fabre. Imagine there is a Green Button Machine through which all human rights violations in a state can be ended by pushing button. ${ }^{5}$ No negative consequences result from the operation of the Green Button Machine. Should external parties be morally permitted, and perhaps even morally obliged, to push the green button? Tesón thinks so. The thought experiment shows that neither communal integrity nor the rights of the state have deeper moral value. For Tesón, unlike Walzer, the only relevant moral considerations determining whether the Green Button Machine should be operated pertain to the protection of human rights.

Yet, Tesón admits, the Green Button Machine and MHI are not entirely analogous. The operation of the Green Button Machine does not have any costs, whereas the use of military force clearly does. To state the obvious, its effects are harmful and damaging. This means that, for maximalist interventionists, not all human rights violations can be addressed through MHI. Sometimes the cost of military action in terms of loss of life and damage to property would be excessive even to the morally desirable goal of ending human rights violations. From the perspective of jus ad bellum, potential intervening parties will often satisfy the just cause criterion but not the proportionality criterion. The challenge, for maximalist interventionists, is to specify a threshold when the proportionality criterion is satisfied. Perhaps this is slightly easier for their minimalist counterparts. Crimes that shock the conscience of mankind are usually so severe that military action is less likely to be disproportionate - or so one could argue.

Since the purpose of this paper is to look at the implications of technology for the ethics of MHI and vice versa, this is not the place to settle the debate between minimalist and maximalist interventionists. Rather, let us briefly consider three ways in which the above observations intersect with technology.

First, questions regarding the morally acceptable costs of MHI (in terms of casualties and levels of destruction) cut across any rigid differentiation between jus ad bellum and jus in bello, regardless of whether one endorses minimalist or maximalist interventionism. This is partly because the (likely) conduct of the intervening party during MHI will determine whether military action does more harm than good. Crucially, this depends on the weapons and other militarily relevant technologies the intervening party has at its disposal. Thus, any moral assessment of MHI at the level of jus ad bellum would need to take into account the intervening party's technological capabilities, as well as its likely in bello conduct.

Second, according to minimalist interventionism, since communal integrity matters morally, interventions should not be overly invasive. Before shifting his position on this issue

\footnotetext{
${ }^{4}$ Cécile Fabre, Cosmopolitan War (Oxford: Oxford University Press, 2012), chapter 5.

${ }^{5}$ Fernando Tesón, Bas Van Der Vossen, Debating Humanitarian Intervention: Should we try to save strangers? (Oxford: Oxford University Press, 2017), 45-49.
} 
in the 1990s, Walzer argued for a quick 'in and out' approach, namely intervention followed by rapid withdrawal. ${ }^{6}$ Compared to a ground invasion, such as Vietnam's intervention in Cambodia to oust the Khmer Rouge in 1977, the availability of precision-strike technology, as well as the reliance on airpower more generally, may make intervention less invasive and therefore more palatable to minimalist interventionists.

Third, for maximalist interventionists, by limiting the damage done by military action, new weapons and other relevant technologies might tilt the scales in favour of a more frequent and stringent enforcement of human rights. To be sure, unlike the operation of the Green Button Machine, military action, in the real world, will never be entirely costless. Yet, new weapons and other relevant technologies might keep the costs of intervention sufficiently low so as to permit MHI more frequently. While, as we just saw, minimalist interventionists are also keen to minimise costs, they would clearly not view this as an opportunity to broaden the scope of interventionism.

With this basic background on the philosophical debate on MHI in place, I now turn to the proposals for assassination and electoral subversion, respectively.

\section{Humanitarian Assassinations and Drones: a Reply to Altman \& Wellman}

Criticising minimalist interventionism, which they refer to as the consensus view on MHI, Altman and Wellman develop a position akin to Tesón's and Fabre's, with a strong emphasis on human rights. ${ }^{7}$ But, like Tesón, they are also worried about disproportionate costs arising from military action. Their response to this problem is twofold. First, they deny that MHI generates disproportionate costs. Secondly, and somewhat contradictorily, they argue that because fully-fledged armed interventions often impose disproportionate costs on members of the target state, potential intervening parties should assassinate political leaders responsible for the worst human rights abuses.

Here, I assume that the concept of an assassination denotes the intentional and targeted killing of a holder of public office or a figure of political significance for political reasons, rather than mere private ones. Ultimately, assassinations seek to settle the question of who controls and governs the state. This accounts for their political character. Since the reasons for assassination cited in Altman and Wellman's proposal pertain to the protection of human rights, I refer to relevant forms of assassination as humanitarian assassinations below. Regardless of their underlying reasons, however, all assassinations, I should add, are highly asymmetric forms of killing. Assassins seek to maximise their chances by minimising the target's ability to evade or defend themselves against the assassination attempt. Assassins strike in unexpected moments, quickly and without warning.

Although good assassins will need to master the Machiavellian skills of cunningness and violence, the means of assassination do not need to be sophisticated. A knife, a gun, or a primitive improvised explosive device (IED) could easily be the entry ticket into the shadowy world of assassins. The only problem is that, while the technological costs of assassination are not necessarily high, the most violent and tyrannical political leaders who could be considered legitimate targets for a humanitarian assassin are usually also extremely paranoid and concerned for their safety. In order to stay in power and survive, they are incredibly adept at neutralising opponents and surrounding themselves with deep layers of personal protection, often secured through material reward in exchange for unquestioning loyalty, or

\footnotetext{
${ }^{6}$ Michael Walzer, "The Politics of Rescue," in Michael Walzer, Arguing About War (New Haven: Yale University Press, 2004), 67-81.

7 Andrew Altman, Christopher Heath Wellman, "From Humanitarian Intervention to Assassination: Human Rights and Political Violence," Ethics 118 (2008):228-257.
} 
ideological manipulation, or straightforward intimidation (after all, as Machiavelli reminds us, it is better to be feared than loved). Because of this, there are two options for would-be assassins. The first is to penetrate the political leader's inner circle in order to kill him in a closed-private (or semi-private) setting, while the second option consists in killing the leader in an open-public setting where he is more readily accessible. Neither option is considered by Altman and Wellman.

By way of historical example, Graf Claus von Stauffenberg and his co-conspirators in the $20^{\text {th }}$ July Plot pursued the first option by seeking to kill Hitler, with a small bomb, at his infamous Eastern European military headquarter, the Wolf's Lair. The complex plot involving high-ranking officers in the German army, as well as prominent members of Germany's upper class, failed on 20 July $1944 .{ }^{8}$ Five years earlier, on 8 November 1939, Georg Elser, a German communist sympathiser and carpenter by trade, had tried to assassinate Hitler in an openpublic setting by placing a home-made bomb at a Munich beer hall (demolished in 1979) where the Fuebrer was due to commemorate the failed Beer Hall Putsch of 1923. The bomb detonated after Hitler had already left, killing eight people and injuring sixty-two others. ${ }^{9}$ The two examples illustrate three salient points about assassinations, namely that, firstly, assassinating a political leader in a closed-private setting is extremely difficult, while, secondly, trying to do so in an open-public setting is extremely risky for bystanders. And thirdly, neither option guarantees success.

Drones, however, may offer a solution to these three problems. Drones are uninhabited aerial vehicles that are remote-controlled by a pilot located in safe distance from the drone's area of deployment. Drones are, to use technological jargon, tele-operated. That is to say, they are equipped with a powerful sensor suite which provides the pilot with a continuous videofeed of the drone's area of operations. Based on what he sees on his screen, the pilot can issue commands to the drone via his remote-control. If the drone is equipped with a payload, the pilot can, via pressing a button on his control console, apply force to a target, usually by launching a missile. The advantages of drones in the context of humanitarian assassinations are as follows.

1. Given that they are remote-controlled, drones meet the political imperative of intervening states to insulate their service personnel from harm during non-selfdefensive operations.

2. Drones are stealthy assassins because they can fly at extremely high altitudes and might not be readily detectable from the ground; hence they maximise the element of surprise necessary for a successful assassination.

3. Drones can remain in the air for long periods of time and thus contribute to a much better intelligence picture.

4. Even though drones fly at high altitude, their sensor suites are capable of generating high resolution images, which makes them preferable over NATO's tactic of highaltitude bombing and similar uses of airpower. During the Kosovo War, aircrews had to rely on preassigned targeting coordinates. Drones, by contrast, offer the pilot a much better situational understanding.

5. The better situational understanding for the pilot introduces an element of flexibility to proceed with or abort an assassination attempt, depending on the circumstances. The drone pilot, for instance, could wait until the time is right before launching a

\footnotetext{
8 Von Stauffenberg was executed by firing squad a day later, on 21 June 1944. See Peter Hoffmann, Stauffenberg: A Family History 1905-1944, $3^{\text {rd }}$ ed (Montreal: McGill University Press, 2008).

${ }^{9}$ Having been held prisoner by the Nazis for five years, Elser was executed in the concentration camp Dachau in 1945, shortly before Nazi Germany's surrender to the Allies.
} 
strike. An assassin whose only chance is to leave an IED close to the route where the leader's convoy is likely to pass does not have that flexibility.

6. Assassinations via drones are likely to take place in open-public settings, rather than in closed-private spaces, though it might be possible to target a leader as he leaves his compound or a private residence. Yet, compared to a lone gunman placed in a crowd or a bomb placed in a beer hall, the risks for bystanders are potentially lower. Drone pilots can, as indicated above, delay delivering the payload until risks for bystanders are as low as reasonably possible.

7. The destructive capability of drones is greater than that of an IED or a lone gunman. Their payloads can penetrate a leader's bunker or armoured convoy. In this sense, they roughly have the same destructive effect as the conventional fighter jets deployed during the Kosovo War and the Libya intervention, yet with fewer risks for civilians and bystanders.

8. Compared to assassinations in closed-private settings, drone missions require less preparation. To be sure, they are highly intelligence-dependent. But the overall planning effort is probably no greater than for assassinations in open-public settings in general. Perhaps it is even slightly lower. Due to the operational flexibility afforded by drones, it might be easier to fly a drone into the target state's airspace than to place an assassin in a convenient location in an openly-accessible area.

These points represent how we have come to think of drones and their deployment in the late 2000s, namely as remote-controlled airplanes armed with a payload. But drone technology does not stand still. Compared to the micro-drones currently under development, remotecontrolled airplanes seem almost clumsy. A micro-drone might not be much larger than an insect and could deliver a minute yet lethal payload undetected. Or consider the lethal possibilities offered by swarms where an operator remote-controls several drones moving in a synchronised fashion. If one drone is intercepted, the remaining drones can still reach their target. This is not to mention the opportunities afforded by advanced levels of automation. ${ }^{10}$ Over time the role of the drone pilot could be reduced in order to allow a drone, once programmed, to engage its target without additional human guidance. As a result, the drone could strike quicker and more stealthily than a remote-controlled device or a human assassin. Without going into further detail, technological progress plays into the hands of Altman and Wellman's proposal. Drones could usher in a new form of interventionism, which is less centred on the classic concept of MHI and large-scale military campaigns. It needs to be clarified, then, whether this would be normatively desirable.

\section{A. Humanitarian Assassination via Drone: Critical Issues}

The first critical challenge to drone-based interventionism focuses on the inherent asymmetry of drone strikes. Targets of a drone strike can hardly defend themselves effectively. Yet, as noted above, all assassinations rely on a degree of asymmetry between the assassin and the target. If asymmetric killing is morally objectionable, Altman and Wellman's proposal is beyond the moral pale, regardless of whether drones are used to implement it. Similarly, one wonders where this leaves NATO's use of high-altitude bombing during the Kosovo War, which, as Ignatieff's observations make clear, was also highly asymmetrical. In fact, the issue of asymmetry may be more pronounced in MHI because of the political (and moral) imperative not to endanger service personnel in a non-self-defensive war. Consequently, if this criticism sticks, it threatens the moral viability of MHI as such. But I doubt that a world

\footnotetext{
${ }^{10}$ See Alexander Leveringhaus, Ethics and Autonomous Weapons (London: Palgrave, 2016).
} 
in which massive human rights abuses continue unabated is morally desirable. Intuitively, asymmetries between the intervening party and its targets seem morally tolerable in order to halt atrocities.

Second, critics could argue that the proliferation of drone technology increases the likelihood of abuse of the permission to conduct humanitarian assassinations. That said, the truth is that any permission to use force can be abused. Imagine that Motorhead wants to appropriate natural resources located in neighbouring Petroleum. To justify an invasion, Motorhead falsely claims that Petroleum is an aggressor. Confronted with this possibility, few would argue that self-defensive wars should be banned. Thus, in order to convincingly oppose the use of drones for humanitarian assassinations, it needs to be shown that such a policy leads to comparatively higher levels of abuse than more accepted uses of force in international society. This is, in the end, an empirical question, rather than a philosophical one.

Third, drawing on a slightly different aspect of the debate on drones, the USA's use of drones for purposes of counterterrorism has been criticised for being shrouded in secrecy, with little opportunity for democratic accountability. ${ }^{11}$ Likewise, in the United Kingdom, the British government only revealed that it had launched drone strikes against two British citizens who had gone to Syria in order to join Daesh (Islamic State/ISIL) after these had taken place. ${ }^{12}$ Contrast this with the heated debates on the eve of the Kosovo War, especially in the German parliament. This was, after all, the first participation in a combat mission for the German Air Force, the Luftwaffe, since 1945. And leaving historical symbolism aside, the Kosovo War was not authorised by the UN Security Council. ${ }^{13}$ Or consider, in August 2013, the equally heated debate in the British House of Commons over potential British support for interventionist efforts in the Syria civil war, which had started two years earlier, in 2011. The then British Prime Minister David Cameron, who wanted to keep the option of military intervention on the table, lost the vote. ${ }^{14}$ By contrast, drone missions have flown, quite literally, under the radar.

Altman and Wellman anticipate this criticism and suggest the creation of an international body with official oversight over humanitarian assassinations. ${ }^{15}$ This body would allow leaders to reply to the charges made against them. But there are two main problems with this solution. The first is that the threat of assassination made by an international body might not work. Before the Kosovo War, for example, the US special envoy for the Balkans, Richard Holbrooke, left the Serbian leader Slobodan Milosevic in no doubt about what would happen if he did not relent. ${ }^{16}$ Milosevic only relented after a one-hundred day bombing campaign. The second problem lies in the paranoid tendencies of powerful leaders. Too much public scrutiny in advance of an assassination will only motivate leaders to increase their personal protection measures. They might cease to travel, fortify their compounds, or round up those who they suspect of leaking information about their whereabouts to the intervening party. Because of this, a successful policy of humanitarian assassination does not lend itself to public accountability and scrutiny. The criticism thus stands.

\footnotetext{
${ }^{11}$ Chris Woods, Sudden Justice: America's Secret Drone Wars (London: Hurst, 2015).

12 BBC News UK, "Islamic State Conflict: Two Britons Killed in RAF Syria Strike" (7 September 2015), available at https://www.bbc.co.uk/news/uk-34178998, Accessed March 27, 2021.

${ }^{13}$ For German perspectives on the Kosovo War, see Reinhard Merkel (ed.), Der Kosovo-Krieg und das Voelkerrecht (Frankfurt a.M: Suhrkamp, 2000).

${ }^{14}$ BBC News UK, "Syria crisis: Cameron loses vote on Syria action" (30 August 2013), available at https://www.bbc.co.uk/news/uk-politics-23892783, Accessed March 27, 2021.

15 Altman, Wellman, "From Humanitarian Intervention to Assassination," 254.

${ }^{16}$ See Judah, Kosovo: $W$ ar and Revenge.
} 
Fourth, sometimes humanitarian assassinations of political leaders carried out via drones may not make the desired difference. It is, for instance, hard to see how a policy of humanitarian assassination would have ended the Rwandan genocide in 1994 during which neighbours, armed with machetes and knives, turned on each other. Moreover, the role of non-state actors, such as Daesh or Boko Haram, has recently become prominent in atrocities. Non-state actors have a looser organisational structure than states: they are more 'root-like' (dispersed) than 'stem-like' (hierarchical). Because of this, the death of their leader might not spell the end of their operations. Semi-autonomous units or 'lone wolfs' could keep on fighting. Further, it makes sense to strike against those carrying out human rights abuses, rather than those who order them. Victims need help now; they cannot wait until a regime has collapsed after the death of its leader.

The above suggests that in order to protect human rights effectively, the mission mandate for intervening parties must (sometimes) be broader than Altman and Wellman's argument in favour humanitarian assassination suggests. Arguably, effective intervention via drones would increasingly begin to resemble the kinds of airpower-based campaigns seen in Kosovo and Libya. The only difference is that they would be conducted with uninhabited and remotecontrolled aircraft, rather than manned fighter planes. Drawing on recent experience, it is noteworthy that Operation Inherent Resolve against Daesh did resemble a classic airpower-centric campaign, though it did include targeted killings carried out via drones. This means that the deployment of drones for interventionist purposes is unlikely to usher in a new form of interventionism. Instead, drone deployment would continue to fall under the concept of MHI or something similar.

Fifth, as we saw earlier, the traditional concept of MHI is regulated via jus ad bellum and jus in bello. If, as I just argued, effective drone-led interventions are likely to resemble other airpower-based campaigns, there is, in principle, no reason why they should not be regulated via these two frameworks. It is less certain, though, what a normative framework for humanitarian assassination via drones should look like. Is it permissible, for instance, to harm innocent individuals when carrying out a humanitarian assassination? Georg Elser obviously thought that killing patrons in a beer hall was an acceptable price to pay to rid Europe of Hitler. But was it? ${ }^{17}$ This is not to suggest that it is impossible to develop a suitable normative framework. But until such framework exists, one should be weary of the use of drones for the implementation of a policy of humanitarian assassination.

Sixth, there is disanalogy between using drones strikes to neutralise terrorists, their most common usage since the late 2000s, and their use for humanitarian assassinations. The elimination of a terrorist presumably means that the threat the person and their organisation poses has ceased to exist. Yet, assassinating a political leader does not necessarily mean that human rights in another state are protected. In a power vacuum, other parties could continue to abuse human rights with impunity. In short, there needs to be a positive structure through which human rights can be enforced and defended. As I already observed in the context of non-state actors, a policy of humanitarian assassinations conducted remotely via drones is not sufficient to guarantee greater respect for human rights in the target state.

To conclude, taking a cue from experiences with drone strikes during the US-led War on Terror, humanitarian assassinations raise familiar issues with regard to public accountability, as well as normatively appropriate rules of engagement. Moreover, taking a cue from experiences with atrocities since the end of the Cold War, it is unlikely that humanitarian

${ }^{17}$ For interesting philosophical discussions of Elser's case, see Lothar Fritze, Die Tötung Unschuldiger: Ein Dogma auf dem Prïfstand (Berlin: deGruyter, 2004) and "Die Bombe im Buergerbraeukeller," Frankfurter Rundschau (November 8, 1999), available at www.georg-elser-arbeitskreis.de/texts/fr19991108.htm, Accessed March 3, 2021. 
assassinations via drones can replace the older concept of MHI. Interventions and their aftermath remain costly and are wrought with political difficulties, notwithstanding the existence of remote-controlled weaponry. On the one hand, this point could lend succour to the minimalist argument to restrict intervention to few instances. For maximalist interventions, on the other hand, drones do not solve the problem of excessive costs arising from a more permissive form of interventionism. So, I suggest here that Altman and Wellman's proposal for humanitarian assassination should be taken with a pinch of salt. In the next part of the paper, I consider a proposal that could truly offer an alternative form of interventionism, namely Fabre's defence of foreign electoral subversion.

\section{Foreign Electoral Subversion and Humanitarian Election Hacking: a Reply to Fabre}

Fabre's maximalist interventionism, as we saw earlier, operates with a comprehensive list of political, civil, and socio-economic human rights. In addition, she argues that human individuals are prime units of moral concern and respect, regardless of their communal affiliation. This position also underpins her defence of foreign electoral subversion (FES). It is morally permissible, Fabre contends, for an intervening party to influence an election in another state in order to prevent an extremist leader from coming to power who would violate the human rights of those under his rule. ${ }^{18} \mathrm{By}$ interfering with the election, the intervening party, Fabre opines, does not violate the right to vote held by citizens of the target state. Under these circumstances, they forfeit their right to vote and therefore do not hold a moral claim against third parties not to interfere with the election. This is because, according to Fabre, voters are not morally at liberty to authorise human rights violations by casting their ballot in favour of an extremist candidate. Fabre, I should add, does not frame this argument as an explicit alternative to MHI. ${ }^{19}$ However, since her work is part of a wider debate on alternatives to war, it is legitimate to probe its relationship with the debate on MHI here.

FES and MHI each have distinctive features that account for their differences. Certainly, both have the protection of human rights as their aim. Yet, in order to achieve this aim, MHI utilises kinetic force whereas FES relies on non-kinetic measures. ${ }^{20}$ Considering Tesón's earlier concerns about the costs of military action, this difference has implications for how one calculates the costs of intervention. Essentially, FES, unlike MHI, does not entail casualties and the destruction of property, though, as I argue shortly, it can sometimes lead to this. The availability of non-kinetic methods to protect human rights also has implications for the permissibility of MHI. If FES was likely to be successful, MHI fails the jus ad bellum criteria of last resort and necessity. More radically, if electoral subversion techniques become increasingly sophisticated and successful, interventionism might become less premised on the use of kinetic force altogether.

Further, compared to MHI, FES has a more ambiguous relationship with the notion of consent. As was noted earlier, the concept of MHI presupposes that military action is

\footnotetext{
${ }^{18}$ Cécile Fabre, “The Case for Foreign Electoral Subversion," Ethics \& International Affairs 32/ 8 (2018): 283-292. Fabre uses two cases in her work on FES. In the first case, the intervening party subverts an election in another state in order to protect its own security-related interests. In the second case, the intervening party subverts electoral processes in the target state because the election of a particular candidate would threaten the human rights of (some) members of the target state. In this paper, I am only interested in the second case.

${ }^{19}$ See James Pattison, Alternatives to War: From Sanctions to Nonviolence (Oxford: Oxford University Press, 2018); Fabre, "Foreign Electoral Subversion," 286-287.

${ }^{20}$ Ibid., 284.
} 
conducted without the target state's consent. It is conceivable, however, that an incumbent head of government standing for re-election might ask a foreign power to subvert the electoral process in his favour. Suppose that the incumbent has a good record on human rights but fears that an extremist challenger could win the election. Fearing for the worst, the incumbent appeals to a third party for help. This indicates that while MHI is by definition non-consensual, FES can sometimes be consensual, at least at the level of the target state's government.

Perhaps one of the more striking differences between the two concepts is that MHI is a reactive response to human rights violations whereas FES is a proactive policy. On the classic concept of MHI, kinetic force is used to end on-going human rights violations. True, states sometimes use military force to prevent imminent massacres, such as, in 2011, the imminent attack by Libyan forces loyal to the late Colonel Gadhafi on the city of Benghazi. But compared to MHI, FES is necessarily proactive in that it seeks to prevent a candidate from coming to power on the basis of what he might do in office. As we shall see shortly, this has important epistemic implications.

That being said, the above differences should not be overstated. FES and MHI are recognisable parts of the philosophical debate on intervention. For example, FES' scope is automatically limited to political systems that are either democratic or at least hold elections. The use of kinetic force, then, remains an option in the case of dictatorial and tyrannical regimes. Further, the distinction between minimalist and maximalist interventionists retains its validity. Minimalists are likely to oppose FES because they value communal integrity and thus seek to protect the integrity of domestic political processes, even if these lead to illiberal outcomes. ${ }^{21}$ Any break with non-intervention norms is strictly a last resort and only legitimate in response to the most extreme atrocities. By contrast, it is not far-fetched to argue that maximalists view interventionist practices as existing on a continuum. If FES fails to protect human rights, interventionist action can be escalated to the levels of humanitarian assassination or MHI.

With a deeper understanding of the relationship between FES and MHI in place, we can now turn to the more specific issues arising from FES.

\section{A. Foreign Electoral Subversion: Conceptual, Philosophical, and Practical Issues}

To refine Fabre's account of FES slightly, it is useful to distinguish between electoral subversion and election hacking. As Fabre notes, it is possible to influence an electoral outcome by paying for the campaign of a particular candidate. ${ }^{22}$ This is arguably one of the most established methods of electoral subversion. From the perspective of technology, however, it does not require a high level of sophistication. Election hacking, as understood here, refers more narrowly to the use of information technology and other relevant digital technologies in order to subvert elections. Given the focus on technology in this paper, the following analysis will mostly be devoted to election hacking. In the current context, the use of information technology raises complex philosophical and practical issues that require a brief discussion.

From a philosophical perspective, information technology is interesting because its effects are widely dispersed and often unintended. For example, during the existence of the Berlin Wall, many East Germans in the communist German Democratic Republic (GDR) were able

\footnotetext{
${ }^{21}$ See Michael Walzer, “The Moral Standing of States. A Reply to Four Critics," Pbilosophy \& Public Affairs 9/ 3 (1980): 209-229.

${ }^{22}$ Fabre, "Foreign Electoral Subversion," 285.
} 
to receive what was then referred to as Westfernsehen (West German television). ${ }^{23}$ The availability of information about the considerably more affluent lifestyle in West Germany contributed, among other factors, to dissatisfaction among East Germans with the GDR's Stalinist regime, resulting in calls for political reform and ultimately German reunification. To be sure, in the political environment of the Cold War, West Germany's political elites and their American backers would not have minded the detrimental effect of Westfernsehen on East German morale. Even so, it is hard to classify the transmission of Westfernsehen to East German households as an intentional policy. That was simply how, in those days, the relevant technology worked: the GDR did not have the means to block West German television signals, and the two countries were obviously so close together that a quick adjustment of one's television antenna would open a window into the 'decadent West.'

Producing dissatisfaction among East Germans, then, was a welcome but non-intentional and merely foreseen side-effect of entertaining and informing West Germans. ${ }^{24}$ Counterfactually, there would have been no reason for West German elites to halt television broadcasting if it had no discernible impact on East Germans. Clearly, like most people, West Germans just wanted to watch television, regardless of its effect on members of another state. By analogy, in cases where election hacking is permissible, it is possible that voters access information about another country and decide whom to vote for on that basis, without the intervening party intentionally providing the information or the access to it. This is surely why authoritarian regimes often restrict access to certain websites, monitor their citizens' internet usage, or block mobile phone signals. In brief, the point I wish to stress here is that in order to be able to speak of election hacking, the intervening party's use of information technology (and other relevant digital technologies) must be intentional. This means that its effects on the electoral process in the target state are intended by the intervening party, rather than merely foreseen and unintended.

From a more practical perspective, even if the intervening party intentionally uses information technology to influence an election, it still needs to be clarified which stage of the electoral process it should target. ${ }^{25}$ One option would be to interfere relatively early by using information technology to urge voters not to vote for an extremist candidate. The intervening party could, among other things, target relevant voters on social media with specific messages tailored to their psychological profile. Alternatively, the intervening party could try to persuade certain voters not to vote. Let us suppose that adverse weather conditions have a negative effect on voter turnout. ${ }^{26}$ Misinformation about weather conditions on polling day may make relevant voter groups stay at home. More controversially, the intervening party could try to attack the target state's digital election infrastructure. For

\footnotetext{
${ }^{23}$ I am grateful to Simon Usherwood for the example.

${ }^{24}$ I appeal loosely to the Doctrine of Double Effect (DDE) here, which distinguishes between what an agent intends and foresees. In situations where an act has good and bad consequences, DDE claims that the agent is allowed to perform the act if, and only if, the good effect is intended and the bad effect is merely foreseen and unintended, subject to proportionality. The case of Westfernsehen differs slightly from standard applications of DDE in that the intended effect seems morally neutral while its unintended side-effect was not morally undesirable. See Warren S. Quinn, "Actions, Intentions and Consequences: The Doctrine of Double Effect," Philosopby \& Public Affairs 18/ 4 (1989): 334-351.

${ }^{25}$ Fabre's own discussion of this issue is organised around the normative criteria that an election must be free and fair. For the purpose of the paper, it is useful to present the issue slightly differently, with less emphasis on the twin requirements of freedom and fairness. Fabre, "Foreign Electoral Subversion," 284-285.

${ }^{26}$ This issue is hugely contested in political science. See Brad T. Gomez, Thomas G. Hansford, George A. Krause, "The Republicans should pray for rain: Weather, turnout, and voting in US presidential elections," The Journal of Politics 69/3 (2007):649-663.
} 
example, it could engage in electronic voter suppression by deleting names of certain eligible voters from an electoral register. Or it could try to prevent certain votes from being counted by manipulating e-voting processes or electronic voting machines. To my knowledge, there is currently no documented case where the last two options have been successfully pursued. But this is not to rule them out for the future. Overall, the intentional hacking of an election for humanitarian purposes is not unfeasible. The question now is whether it is also morally and politically sound.

\section{B. Electoral Subversion as Non-Kinetic Intervention: some Critical Issues}

Without critiquing Fabre's account of forfeiture as such, I outline several challenges to election hacking below. To begin, the intentional hacking of digital election infrastructure to either prevent people from voting or to ensure that their vote is not counted is self-defeating. If the manipulation came to light, it would provide a reason for the target state to annul the election result and hold another vote: this time in full knowledge that a foreign party had previously undermined its digital election infrastructure. This is bound to result in political disaster. Alternatively, an extremist politician might declare the election result invalid and grab power without another vote. For these reasons alone, the hacking of digital election infrastructure should be discounted.

More realistically, the intervening party might try to either change voters' minds or persuade them not to vote. But unfortunately, these two options are also fraught with difficulty. Consider US President Barack Obama's intervention in the UK's 2016 referendum on its membership of the European Union. ${ }^{27}$ In this case, it was clear who the speaker was (Barack Obama), on whose behalf he was speaking (the American government), why he was speaking (he had been invited by the then British Prime Minister David Cameron), and what the message was (vote to stay in the European Union). This example, however, is not representative of actual election hacking where information technology is regularly used to disguise the true identity of the intervening party and circulate misleading statements or blatant lies. For, if it was obvious that a particular statement was made by a foreign power, it would not have the desired effect on voters' attitudes. In fact, it could easily be weaponised by the intervening party's opponents. Partly in response to President Obama's intervention, for instance, Boris Johnson, the most prominent pro-Brexit campaigner who would go on to become UK Prime Minister in 2019, made the racist, but widely circulated, claim that the President only opposed Brexit because his Kenyan heritage meant that he had an 'ancestral dislike' of Britain. 28

As one can see, successful election hacking that seeks to change voters' attitudes or discourage them from voting entails a certain level of deception and possibly lying, either about the identity of the messenger or the content of the message (for example, that it will rain on polling day) or both. From a political perspective, the use of deception during election hacking gives rise to a problem, which I already highlighted in my discussion of humanitarian assassination. To recap, I argued that the secrecy surrounding assassinations undermines a commitment to political accountability within the intervening party. Likewise, if it is only

\footnotetext{
${ }^{27}$ BBC News UK, "Barack Obama says Brexit would leave UK at the 'back of the queue' on trade" (April 22, 2016), available at https://www.bbc.co.uk/news/uk-36115138, Accessed March 27, 2021.

28 President Obama's father was Kenyan while his mother was a white Caucasian American. The row between Mr Johnson and the President had initially erupted over the President's removal of a bust of Winston Churchill from the Oval Office in the White House. See BBC News UK, "Obama hits back at Boris Johnson's alleged smears" (April 22, 2016), available at https://www.bbc.co.uk/news/uk-politics36112694, Accessed March 27, 2021.
} 
possible to successfully change the minds of voters in the target state by disguising the true identity of the intervening party, election hacking will have to involve a high degree of secrecy, with little public oversight. In this sense, one could argue that election hacking not only undermines democracy abroad; it also undermines it at home (insofar as the intervening party is a democracy).

Regardless of whether the issue of political accountability can be solved, from a moral perspective, lying and deception remain enormously complex topics. ${ }^{29} \mathrm{~A}$ few short observations relevant to election hacking will have to suffice for now. Intuitively, statements that obscure the intervening party's identity and contain misinformation are more problematic than statements that only obscure the intervener party's identity but contain correct information. Further, one could make backward- and forward-looking arguments in favour of deceiving voters in the target state. A backward-looking argument would deem deception permissible because voters in the target state have forfeited their right to vote, whereas a forward-looking argument would contend that deception pre-empts the need for kinetic, and thus riskier and costlier, interventionist responses in the future. Arguably, the forward-looking argument's rationale, that it is better to deceive voters during an election than harm them in the course of MHI, is not unattractive. The problem with the backward-looking argument, by contrast, is that it only shows that voters in the target state lack a claim against the intervening party not to hack an election. It tells us little about the means the intervening party can permissibly adopt for the purpose of election hacking, and especially whether it is allowed to disguise its identity and spread misinformation. Here, the contrast between MHI and election hacking could not be clearer. Notwithstanding disagreements over its correct interpretation, jus in bello provides the rules of engagement for MHI. A comparable framework is lacking for election hacking.

Leaving aside whether either the backward- or forward-looking argument succeeds in justifying the deception of voters in the target state, the large-scale use of deceptive messaging might be an unwise strategy to adopt. The pernicious effect of widespread and constant lying and deception in political life is the loss of trust in a political system. ${ }^{30}$ In fact, it is likely that in cases where election hacking is permissible a society is already deeply polarised, with low levels of trust in public institutions and the media. Deception by a foreign party could pour oil into the fire. Rather worryingly, it not inconceivable that counternarratives of betrayal, deception, lies, and foreign meddling could result in post-election violence and human rights violations - perhaps even necessitating the use of kinetic force to quell unrest. This means that intervening parties are stuck between a rock and a hard place. If, on the one hand, they are honest about who they are, they are unlikely to persuade sufficient numbers of voters to cast their ballot in favour of a moderate candidate. If, on the other hand, they deceive voters, they undermine trust in the target state's political system, with negative effects for the peaceful transition of power.

The above point about the erosion of trust is compounded by the profusion of information technology. Third parties allied to an extremist candidate could easily use information technology to launch a counter-intervention against the intervening party. Generally, the issue of counter-intervention has been neglected in the ethical debate on interventionism. ${ }^{31}$ In cases of MHI, the implicit assumption seems to be that the intervening party is technologically superior to the target state and its allies, and that the latter are unwilling to come to the defence of the former. The practice of MHI in the twentieth century appears to confirm this. Information technology, by contrast, acts as a great equaliser. If an

\footnotetext{
${ }^{29}$ See Thomas L. Carson, Lying and Deception: Theory and Practice (Oxford: Oxford University Press, 2010).

${ }^{30}$ See Onora O’Neill, A Question of Trust (Cambridge: Cambridge University Press, 2002).

${ }^{31}$ Walzer, Just and Unjust Wars, 95-100.
} 
intervening party seeks to suppress voter turnout by flooding social media with misinformation that it will rain on polling day, another party could easily counter this message by flooding social media with information that the weather will be wonderful. This not only undermines the efficiency of election hacking for humanitarian purposes; in an atmosphere of warring claims and counterclaims, it could further undermine trust in the target state's political system.

The final challenge I want to discuss here pertains equally to election hacking as well as more traditional forms of FES. Fabre imagines a situation where a (supposedly) moderate candidate falsely suggests that he will not commit human rights abuses (or escalate a conflict), despite having plans to do so. Conversely, an extremist candidate, Fabre points out, may be playing to the gallery of his most radical supporters, without having any intentions to abuse human rights after winning the election. In both cases, Fabre is primarily interested in whether it is fair that deceived voters should forfeit their right to vote - a question which she answers affirmatively. ${ }^{32}$ Even so, the intervening party is faced with considerable epistemic problems, which is not surprising given that proactive, rather than reactive, policies involve speculation about the future. To be precise, the question is whether the intervening party should base its policy of election hacking on the assumption that a particular candidate, once elected, will or will not commit human rights abuses. That can be difficult.

To illustrate the point, in the first election in post-apartheid South Africa (1994), an intervening party could have had a justification for preventing Nelson Mandela and the ANC from winning power. ${ }^{33}$ The ANC's youth wing, led by Mr Mandela's then (estranged) wife Winnie, was radical. Certainly, Mrs Mandela's attitude towards white South Africans was less tolerant than her husband's. ${ }^{34}$ The danger was that if Mr Mandela's first government had been captured by the most radical factions of the ANC, it could have implemented policies that greatly reduced, or even violated, the rights of white South Africans, for example, by expropriating them. Apart from the bitter taste that even the theoretical prospect of black South Africans forfeiting their right to vote leaves in one's mouth, it is ludicrous to suggest that a foreign power should have prevented Mr Mandela, an icon of the twentieth-century and Nobel Peace Prize Laureate (1993), from winning the election. Nevertheless, the example shows how difficult it is for an intervening party to know in advance whether or not a radical faction might come to dominate a political party after an election. At least the ideological preferences of Mrs Mandela and her comrades were widely known. The possibility that a particular candidate might be the proverbial wolf in sheep's clothing or a sheep in wolf's clothing compounds the epistemic difficulties faced by the intervening party.

To take stock, from an interventionist perspective, election hacking appears appealing because it is a non-kinetic form of interventionism and reduces the need for MHI by preventing extremist leaders from coming to power. But notwithstanding the capacity of information technology and other relevant digital technologies to facilitate election hacking, the practical options for intervening parties are limited. They largely consist in changing the opinions of voters in the target state or discouraging them from voting. Neither of these two options is unproblematic. In both cases, the need for deceptive messaging could undermine trust in the political system of the target state, as well as reinforce existing societal polarisation. Moreover, the need for secrecy could undermine a commitment to accountability in the intervening party. Finally, any attempt to justify election hacking (and FES more broadly), like

\footnotetext{
32 Fabre, "Foreign Electoral Subversion," 288-289.

33 I thank Christopher Macallister for suggesting this example.

34 Reuters, "Winnie Mandela, tarnished 'Mother' of post-apartheid South Africa" (April 4, 2018), available at https://www.reuters.com/article/us-safrica-winniemandela/winnie-mandela-tarnishedmother-of-post-apartheid-south-africa-idUSKCN1H91A6, Accessed March 10, 2021.
} 
all proactive policies, faces almost insurmountable epistemological difficulties. In short, whatever one makes of Fabre's claim about the forfeiture of the right to vote, the scaffold for a sound normative account of election hacking is high.

\section{Where Next for Technology and Interventionism?}

Before I conclude the paper, I want to offer some brief thoughts on the role of technology in interventionism, as well as the protection of human rights in general. Hopefully, these can serve as a starting point for a future research agenda on the implications of technology for the ethics of intervention. In light of the above analysis, perhaps the problem is that participants in the debate on intervention remain too wedded to the classic concept of MHI, where outsiders directly intervene in another state's sovereign domain and take it upon themselves to protect the human rights of the target state's members; be it by assassinating a tyrannical leader via a drone strike or hacking an election or more conventional methods of warfare, such as high-altitude bombing. It makes sense, however, to think about the relationship between the ethics of intervention, technology, and human rights in a broader way.

One aspect of interventionism that has been much maligned in recent years is the Responsibility to Protect (R2P). R2P was developed by the International Commission on Intervention and State Sovereignty (ICISS) in the aftermath of the Kosovo War and was formally adopted by states at the UN World Summit in 2005, albeit in truncated form. ${ }^{35}$ Nevertheless, R2P contains an interesting idea. It maintains that the international community has a responsibility to assist states in meeting their own responsibilities towards their members. Under the R2P framework, the primary responsibility a state has towards those under its rule is to protect them from atrocity crimes. Regardless of whether or not one agrees with $\mathrm{R} 2 \mathrm{P}$, this argument presents a valuable point of orientation for thinking about the role of technology in the protection of human rights.

Let me give two brief examples of how states could utilise their technological capacities to assist another state in meeting its own responsibilities towards its members. In the first example, a hostile foreign power, Red, tries to hack an election in a democratic but unstable state called Blue, with the aim of bringing an extremist candidate to power. The extremist candidate is likely to enact policies that violate the human rights of some of Blue's members, but Red calculates that compared to his moderate competitor, the extremist candidate will, once in office, initiate a friendlier foreign policy towards Red. In response, Green could make its digital expertise available to Blue in order to increase the resilience of Blue's digital election infrastructure against potential hacking attempts from Red. In doing so, Green would not subvert the impeding election in Blue. Rather, Green assists Blue in guaranteeing a fair and free election for all its citizens.

In the second example, a non-state actor carries out human rights abuses in Yellow's territory. As was pointed out earlier, one of the assumptions underpinning the classic concept of $\mathrm{MHI}$ is that states are the main abusers of the human rights of their members. However, if one takes into account recent experiences with extremist organisations such as the aforementioned Daesh or Boko Haram, non-state actors, with their root like structures, can pose a significant threat to human rights. Rather than directly becoming active in Yellow's territory by assassinating the leadership of the non-state actor in question, Orange could make certain technologies, such as drones, available to Yellow so that Yellow can regain control over its territory. True, this is plain old foreign military assistance. But it might be far more effective than direct kinetic or non-kinetic interventionist action by Orange.

${ }^{35}$ See Alex J. Bellamy, The Responsibility to Protect: A Defense (Oxford: Oxford University Press, 2015). 
A further suggestion to improve the protection of human rights is to exploit existing and emerging technologies in order to build an evidentiary base for human rights violations. In the above analysis of FES, I pointed out the epistemic difficulties faced by proactive approaches to the protection of human rights. But even the more reactive approach of MHI is bedevilled by epistemic restrictions. Just how can potential intervening parties know exactly what is going on in the target state? Technology can play a vital role in documenting human rights abuses or spotting potential patterns of behaviour that may lead to atrocities. For example, information technology could be used to monitor social media for hate speech or direct calls for violence, while drones may be utilised to document human rights abuses in remote areas. This could either pre-empt the need for direct intervention or make such interventions more effective, if needed.

Finally, struggles for democracy and the better protection of human rights are always local, even if they seek to realise universal values. ${ }^{36}$ Now, if local action is required, a third party should refrain from hacking the political processes in a state that is either hostile to a prodemocracy movement or where such a movement is in danger of losing an election to an authoritarian challenger. It might be a better idea for the third party to make relevant information technology available to local activists so they can effectively counter authoritarian messaging. This is, of course, the tried and tested policy of civil society support and engagement. While the conceptual and normative boundaries between civil society support and FES can be blurry, the advantage of the former over the latter is that it leaves the (voting) rights of local populations intact. Most importantly, third parties do not need to deceive members of the target state. Rather, their technological and logistical support enables democratic movements to build local political and social coalitions to establish or maintain democratic institutions and protect human rights.

Naturally, the above suggestions are no panacea. Nor do they rule out the need for more direct forms of intervention, from classic MHI to humanitarian assassination or election hacking. Still, they illustrate the wide-ranging role technology can play in the protection of human rights once one moves beyond the paradigm of direct intervention.

\section{Conclusion}

In this paper, I examined the normative implications of technology for the ethics of intervention and vice versa. This is a commonly neglected issue in the philosophical literature on the subject. The paper yielded four main insights. First and foremost, my analysis showed that an interest in, and appreciation of, the role of technology in interventionist practice should be central to the ethics of military humanitarian intervention. Roughly, I argued that normative approaches that take a more permissive view on the use of non-self-defensive force are likely to welcome the capacity of some technologies to lower the costs of military action, thereby facilitating a more stringent enforcement of human rights. By contrast, while more restrictive approaches to intervention, such as Walzer's, would also clearly welcome a reduction of relevant costs, they are likely to be wary of broadening the scope of interventionism. I suggested that these two positions retain their validity with regard to interventionist practices that transcend the traditional concept of military humanitarian intervention. This is because they represent fundamental philosophical disagreements about the status of human rights, the moral standing of the individual, and the role of the state in international politics.

\footnotetext{
36 See Michael Walzer, “On Promoting Democracy," Ethics and International Affairs 22/ 4 (2008): 351355.
} 
Second, the paper highlighted that technology can sometimes facilitate the development of new forms of interventionism that move beyond the traditional concept of military humanitarian intervention, with its emphasis on the use of kinetic force and large-scale military operations. By comparison, humanitarian assassinations via drones, at least in theory, entail uses of kinetic force on a much smaller scale, whereas foreign electoral subversion is non-kinetic.

Third, certain technologies have the potential to realise recent ethical proposals in the intervention debate. I scrutinised two of these in the paper, namely humanitarian assassinations and foreign electoral subversion. Drone technology makes it theoretically possible to implement a policy of humanitarian assassination, whereas information technology and the ability to attack another state's digital election infrastructure could be utilised for the purpose of foreign electoral subversion. As my analysis revealed, each proposal faces a number of critical challenges that require further philosophical treatment. However, both proposals share three rather worrisome problems, which raise questions about their moral desirability:

- Neither humanitarian assassination carried out via drones nor electoral subversion carried out with information technology (and other relevant digital technologies) may be particularly effective in protecting human rights.

- Compared to the traditional frameworks of jus ad bellum and in bello that regulate the conduct of military humanitarian intervention, humanitarian assassination and foreign electoral subversion currently lack rules of engagement.

- Since humanitarian assassination and electoral subversion necessitate high levels of secrecy, they undermine political accountability for, and public scrutiny of, interventionist action.

Whether it is possible to solve these problems remains to be seen. Only that would settle whether these new forms of interventionism really are desirable. Either way, one thing is clear: regardless of how technology progresses, neither humanitarian assassinations nor foreign electoral subversion will be able to entirely replace the classic concept (and practice) of military humanitarian intervention. If anything, the two proposals may complement it, rather than replace it. This means that the challenges posed by military humanitarian intervention will not go away any time soon. That said, I also suggested that there are other useful frameworks for thinking about technology in the context of interventionism and human rights protection. These range from the Responsibility to Protect to the classic foreign policy tools of military assistance and civil society support.

Overall, the paper has shown that, in ethical debates on intervention, a deeper engagement with technology is theoretically fruitful, as well as necessary. In addition, the above discussion indicated that greater awareness of relevant practical examples can throw ethical issues arising from the use of technology, as well as recent proposals in the debate on intervention, into sharp relief.

\section{Acknowledgements}

The Leverhulme Trust provided funding for this research via an Early Career Fellowship [ECF-2016-643]. I also received SEED funding from the University of Surrey's Faculty of Art and Social Sciences (FASS) for a small project called 'Bots of Hate' on which the material in the fourth part of the paper is based. The Trust's and FASS' respective funding contributions are gratefully acknowledged. In February 2021, the paper was presented in the research seminar of the Department of Politics at the University of Surrey. I am immensely 
grateful to colleagues for their constructive feedback. Some of the arguments contained in the fourth part of the paper were first presented at the Surrey Centre for Law and Philosophy's (SCLP) annual workshop on Artificial Intelligence in March 2019. I would like to thank all participants for their responses. Finally, I am grateful to Sir Michael Aaronson, Nick Kitchen, and Nicola Leveringhaus for their written comments on this paper, as well as Simona Guerra, Simon Usherwood and Steven Van Hauwaert for kindly sending me relevant material on elections.

\section{References}

Altman, Andrew, Wellman, Christopher Heath. "From Humanitarian Intervention to Assassination: Human Rights and Political Violence.” Ethics 118 (2008):228-257.

BBC News UK. "Barack Obama says Brexit would leave UK at the 'back of the queue' on trade" (April 22, 2016). Available at https://www.bbc.co.uk/news/uk-36115138. Accessed March 27, 2021.

BBC News UK. "Obama hits back at Boris Johnson's alleged smears" (April 22, 2016). Available at https://www.bbc.co.uk/news/uk-politics-36112694. Accessed March 27, 2021.

BBC News UK. "Islamic State Conflict: Two Britons Killed in RAF Syria Strike" (7 September 2015). Available at https://www.bbc.co.uk/news/uk-34178998. Accessed March 27, 2021.

BBC News UK. "Syria crisis: Cameron loses vote on Syria action" (30 August 2013). Available at https://www.bbc.co.uk/news/uk-politics-23892783. Accessed March 27, 2021.

Bellamy, Alex J. The Responsibility to Protect: A Defense. Oxford: Oxford University Press, 2015.

Carson, Thomas L. Lying and Deception: Theory and Practice. Oxford: Oxford University Press, 2010.

Fabre, Cécile. “The Case for Foreign Electoral Subversion.” Ethics \& International Affairs 32/ 8 (2018): 283-292.

—. Cosmopolitan War. Oxford: Oxford University Press, 2012.

Fritze, Lothar. "Die Bombe im Buergerbraeukeller." Frankfurter Rundschau (November 8, 1999). Available at https://www.georg-elser-arbeitskreis.de/texts/fr19991108.htm. Accessed March 3, 2021.

—. Die Tötung Unschuldiger: Ein Dogma auf dem Prüfstand. Berlin: deGruyter, 2004.

Gomez, Brad T., Hansford, Thomas G., Krause, George A. "The Republicans should pray for rain: Weather, turnout, and voting in US presidential elections." The Journal of Politics 69/3 (2007):649-663.

Hoffmann, Peter. Stauffenberg: A Family History 1905-1944. $3^{\text {rd }}$ edition. Montreal: McGill University Press, 2008.

Ignatieff, Michael. Virtual War: Kosovo and Beyond. London: Vintage, 2001.

Judah, Tim. Kosovo: War and Revenge. $2^{\text {nd }}$ edition. New Haven: Yale University Press, 2002.

Leveringhaus, Alexander. Ethics and Autonomous Weapons. London: Palgrave, 2016.

Merkel, Reinhard (ed.). Der Kosovo-Krieg und das Voelkerrecht. Frankfurt a.M: Suhrkamp, 2000.

O’Neill, Onora. A Question of Trust. Cambridge: Cambridge University Press, 2002.

Pattison, James. Alternatives to War: From Sanctions to Nonviolence. Oxford: Oxford University Press, 2018.

Quinn, Warren S. "Actions, Intentions and Consequences: The Doctrine of Double Effect." Philosophy \& Public Affairs 18/ 4 (1989): 334-351.

Reuters. "Winnie Mandela, tarnished 'Mother' of post-apartheid South Africa" (April 4, 2018). Available at https://www.reuters.com/article/us-safrica-winniemandela/winnie- 
mandela-tarnished-mother-of-post-apartheid-south-africa-idUSKCN1H91A6. Accessed March 10, 2021.

Tesón, Fernando, Van Der Vossen, Bas. Debating Humanitarian Intervention: Should we try to save strangers? Oxford: Oxford University Press, 2017.

Walzer, Michael. Just and Unjust Wars: A Moral Argument with Historical Illustrations. $5^{\text {th }}$ edition. New York: Basic Books, 2015.

—. "On Promoting Democracy." Ethics and International Affairs 22/ 4 (2008): 351-355.

—. Arguing About War. New Haven: Yale University Press, 2004.

—. "The Moral Standing of States. A Reply to Four Critics." Philosopby \& Public Affairs 9/ 3 (1980): 209-229.

Woods, Chris. Sudden Justice: America's Secret Drone Wars. London: Hurst, 2015. 